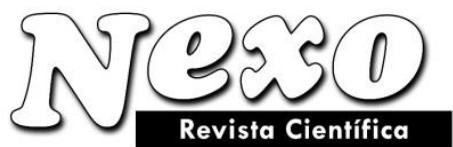

Vol. 34, No. 01, pp. 74-81/Marzo 2021
ISSN-E 1995-9516

Universidad Nacional de Ingeniería COPYRIGHT @ (UNI). TODOS LOS DERECHOS RESERVADOS http://revistas.uni.edu.ni/index.php/Nexo https://doi.org/10.5377/nexo.v34i01.11286

\title{
Digital transformation of russian economy: challenging the highest rank in the global innovation development
}

\section{Transformación digital de la economía rusa: desafiando el rango más alto en el desarrollo de la innovación global}

\author{
Gennadiy I. Lazarev ${ }^{1 *}$, Tat'ayna V. Varkulevich ${ }^{2}$, Viacheslav A. Andreev² \\ ${ }^{1}$ Vladivostok State University of Economic and Service, Vladivostok, Gogolya, 41, the Russian \\ Federation \\ ${ }^{2}$ Department of economics and management, Vladivostok State University of Economic and Service, \\ Vladivostok, Gogolya, 41, the Russian Federation
}

(recibido/received: 15-December-2020; aceptado/accepted: 27-February-2021)

\begin{abstract}
A simple prognostic method was applied to estimate the percentage ratio of the digital economy in Russia's GDP relying on technology solutions expenditure and sectoral investment. The research indicates a significant impact of Russia's digital sector on innovation development in B2B, B2G, and B2C segments. The prognostic analysis shows the extension of on-line education, social networking, e-commerce, private and corporate banking, and end-to-end technology solutions in manufacturing. The findings point at the opportunity for the sectoral investment extension and steady annual growth 7-8 \% in the next few years. Due to requirements on updating the technological solutions in the related public services, the digital sphere can support the annual growth in the national economy by 1,0-1,2 \% until 2024. Respectively the digital economy in Russia will be growing faster the world's average to provide the sector's contribution of 8,0-8,1 $\%$ in GDP by 2024. The findings show the digital platforms are becoming a driver for innovation development integrating the production process, cloud resources, data analysis, and e-learning services. The research contains hints on improving the research efficiency and winning the talent battle that promises to improve the country's global innovation and economic ranks.
\end{abstract}

Keywords: digital economy, innovation development, digital platforms, cloud solutions.

\section{RESUMEN}

Un método de pronóstico simple aplicado para estimar la relación porcentual de la economía digital en el PIB de Rusia que se basa en el gasto en soluciones tecnológicas y la inversión sectorial. La investigación indica un impacto significativo del sector digital de Rusia en el desarrollo de la innovación en los segmentos 
B2B, B2G y B2C. El análisis de pronóstico muestra la extensión de la educación en línea, las redes sociales, el comercio electrónico, la banca privada y corporativa y las soluciones tecnológicas integrales en la fabricación. Los hallazgos apuntan a una oportunidad para la extensión de la inversión sectorial y un crecimiento anual constante del 7-8\% en los próximos años. Debido a los requisitos de actualización de las soluciones tecnológicas en los servicios públicos relacionados, la esfera digital puede soportar el crecimiento anual de la economía nacional en un 1,0-1,2\% hasta 2024. Respectivamente, la economía digital en Rusia crecerá más rápido que la media mundial para proporcionar la contribución del sector 8,0-8,1\% en el PIB para 2024. Los hallazgos muestran que las plataformas digitales se están convirtiendo en un motor para el desarrollo de la innovación integrando el proceso de producción, los recursos en la nube, el análisis de datos y los servicios de aprendizaje electrónico. La investigación contiene sugerencias para mejorar la eficiencia de la investigación y ganar la batalla del talento que promete mejorar la innovación global y la clasificación económica del país.

Palabras clave: economía digital, desarrollo de innovación, plataformas digitales, soluciones en la nube.

\section{INTRODUCTION}

Despite a relatively high rank of the digital economy in its respective sectors, e.g., Internet penetration, an extension of the public on-line services, and the implementation of large-scale digital projects, the sectors' contribution to the Russian economy is significantly smaller in comparison with the advanced countries. Conducting the digital transformation processes, Russia lags behind the leading countries in terms of competitiveness and human capital quality.

The digital sphere contribution is approximately 3-3,6 \% of GDP, while 7-12\% of GDP in the leader countries. As a result, the country has fallen behind the leaders of innovative development, such as Switzerland. A leader in the Global Innovation Index ranking, Switzerland has been taking the first rank for the last several years with 67,2 points in 2019, while Russia has 49 ranks with 37,6 points. By 2024 , the Russian Federation government is going to implement the Digital Economic program and raise investments into the sector by 3-3,5 times (The World Bank, 2018).

According to the Global information technologies report, the Russian Federation takes 41 ranks in digital economy readiness (NRI network readiness index), occupying a place in the middle of the second group of countries in the Digital Economy and society index (I-DESI). The citizens recognize the need to have a digital competency, but using of personal computers and the Internet and telecommunications network in the Russian Federation is still lower than in Europe. There is a gap in digital skills between different population groups. In 2018 , the proportion of the population with digital skills was only $26 \%$, according to an international PIAAC study. The application of digital technologies in universities is expanding, but the number of specialized courses and compliance of educational programs with the digital economy's needs is not sufficient (Varkulevich, 2018; Petruk, 2018).

The core issue is winning the talent battle. Russia's low position in the Global Talent Competitiveness Index (53-rd position in 2018) reflects a low human potential in the development of digital technologies in the economy. It determines the need to attract qualified foreign specialists and support talented schoolchildren and students in the field of mathematics and computer science (The World Bank, 2018; Strack et al., 2018).

\section{MATERIALS AND METHOD}

A simple prognostic method was applied to estimate the percentage ratio of the digital economy in GDP, relying on calculating technology solutions expenditure and sectoral investment. For the purpose of analysis, some assumptions were made to measure digital penetration in business. First, the digital market is strongly 
undervalued. Reports on technological innovation expenditures of corporations and SMEs in the digital economy spheres show 47,36 billion USD in 2019, which is about 3-3,6\% of GDP. In advanced economies, this proportion is $7-12 \%$ of GDP.

The market points to opportunities for extension of sectoral investment that provides a steady annual growth $7-8 \%$ for the next few years following the requirements to update the related public services' technological solutions. Second, the digital sphere can facilitate annual growth 1,2-1,9\% of the national economy until 2024 due to its moderate risk and high value-added business approach. Respectively the digital economy in Russia must be growing faster than the world's leaders to provide the sector's contribution of $8,0-8,1 \%$ in GDP by 2024.

The prognostic analysis made in relatively comfortable macroeconomic conditions relaying the current statistics on technology innovation expenditure and trade of IT equipment, services, software, and digital telecommunications. Meanwhile, a strong uncertainty was noted on the sector's prospects due to the Russian economy's oil and gas incomes. It should bear in mind that economic growth in Russia is influenced by global oil price fluctuations that may stipulate a slowing down the digital economy processes.

BCG's report predicts that the digital economy's share in Russian GDP will be growing and reach 5,6\% by 2021. A more optimistic forecast shows $6,0 \%$ growth due to the ongoing sectoral statistics. A simple prognostic method gives a broad differentiation of the digital economy's share in GDP until 2024. For adjustment noted that in advanced countries, the digital sector's size is 6-7\% of GDP. For instance, in France - 5.7\%, in Germany - 6.3\%, in Great Britain - 7.1\%, in the USA - 7.4\%, in Sweden - 8.6\% (The Boston Consulting Group, 2017).

\section{RESULTS}

The penetration of digital solutions in Russian business is still far behind. Meanwhile, several sectors have a dominant digital market share in their respective segments, e.g., the state and municipal public services, banking sphere, public education, and Internet consumer services. Despite up-to-date technology solutions, the transformation is slowing down. The enterprises still not have broadly performed on-line. They lag behind in applying the digital systems of automation of business processes in comparison with the European business.

Comparatively to the EU countries, Russia is still in its very early stage in applying the resource planning systems (ERP), customer relationship management systems (CRM), and radio frequency identification (RFID) (Figure 1). However, in some sectors, Russia demonstrates advanced digital solutions, for example, Internet penetration in households and businesses. In 2019, Internet access was provided to $87 \%$ of households and $89 \%$ of enterprises. Russia is successfully extending the on-line government services. The country took 25 places in 2018 in the UN ranking of the state on-line services development. 


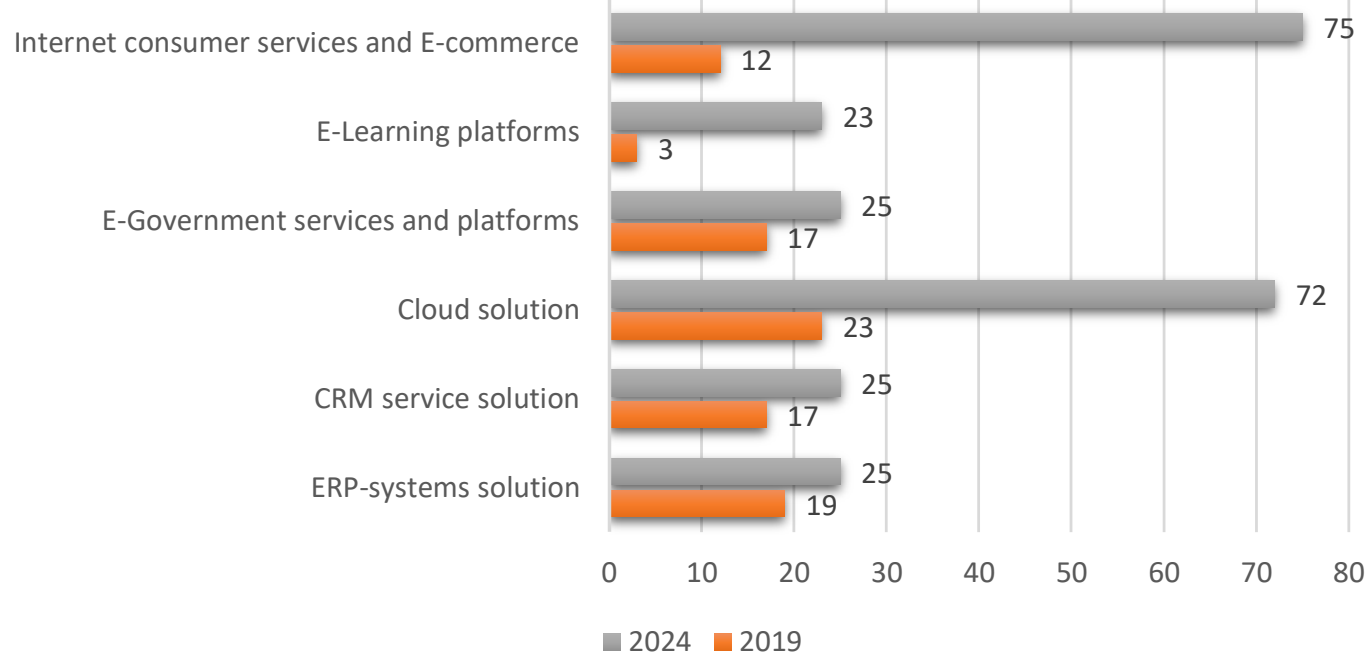

Figure 1. Digital solutions penetration in Russia's business sector ${ }^{1}$

In 2015, the National Platform for Open Education association, with the support of the Ministry of Education and Science of Russia, launched the on-line Open Education platform with the purpose to link the top 9 out of 814 Russian universities. Realization of the National Platform for Open Education project implies 23\% penetration of e-learning solutions in Russia's education sector in 2024 (Figure 1). A prospective segment of on-line education demonstrates annual growth of 20-25\%. At the end of 2019, the sales of e-learning solutions reached 850-900 million USD.

Simultaneously, the world market of on-line education is 74 billion USD, Russia. Thus, Russia occupies only about $1 \%$ of its structure. Meanwhile, presently more than 120,000 students are attending 140 on-line training courses on this national platform. Additionally, some popular non-government digital educational platforms perform e-learning, such are the Lectorium, the Universariu, Uniweb, and so on. Leading Russian universities also represented on global educational platforms like Coursera and EdX.

Russian government follows the most digitally advanced countries and adopts the "government as a platform" (GaaP) approach to represent the public services in a more efficient and user-friendly way. Egovernment services and related platform-based information sources provide 102-103\% annual growth until 2024 and stipulate penetration $25 \%$ in the public governance sphere (Figure 1). It should be noted that the implementation of GAAP in Russia is still in a very early stage. The website gov.ru assumed to reflect the functions of government and to provide unified access to the federal, regional, and municipal services, yet today it remains largely a website offering links to other government websites (Di Maio et al., 2015).

The back-end transformation of the public on-line services is slowing down due to slow business processes' reengineering and data management processing. The government is going to transfer 90 percent of data resources into the cloud by 2024 , but the result is not so optimistic due to data readability problems. The information is not properly structured and not conveniently accessible for users. The problem complicates external and internal users' ability to apply advanced data analytics to launch services and make evidencebased decisions. The regional segregation of data sources also produces additional obstacles to optimization (The World Bank, 2018; Margetts \& Naumann, 2017).

\footnotetext{
${ }^{1}$ Digital economy share in business sector excluding financial sector, \%, 2019 fact, 2024 prognosis
} 
There are opportunities for SMEs businesses, which can efficiently promote their products and services and make payments through platforms provided by big companies. The revenue of Russian digital platforms exceeds 17 billion USD, with about 1 percent of Russian GDP. According to recent statistics, 176 platform companies already represent 4.3 USD trillion in market capitalization worldwide through the value-creating power of their platform ecosystems and digital assets (Finck, 2017). Digital platforms penetrated into a range of sectors, including social networking, employment, tourism, construction, health, e-commerce. Ecommerce platform services are steadily extending 5-5,7\% annually. It provides penetration of $75 \%$ into the business sector and gives small businesses access to regional and global markets to 2024. We can remark that the value of global trans-border e-commerce would grow to 994 USD billion in 2020 (Evans, 2013).

Despite the relatively small size of the digital sector, it has not yet been fully realized its growth potential. Analysis of Russia's digital solutions market shows that it can constantly expand in various business segments due to a low base. The digital sphere contribution in GDP will be growing faster than the world average, and by 2024, the share will respectively be $8,1 \%$ (Figure 2). Digital platforms are steadily becoming drivers that improve the production process and provide the integration of Industrial Internetsupported smart machinery, cloud resources, security solutions, data analysis, and digital workforce with logistics and business-to-business (B2B) and business-to-consumer (B2C) sales processes.

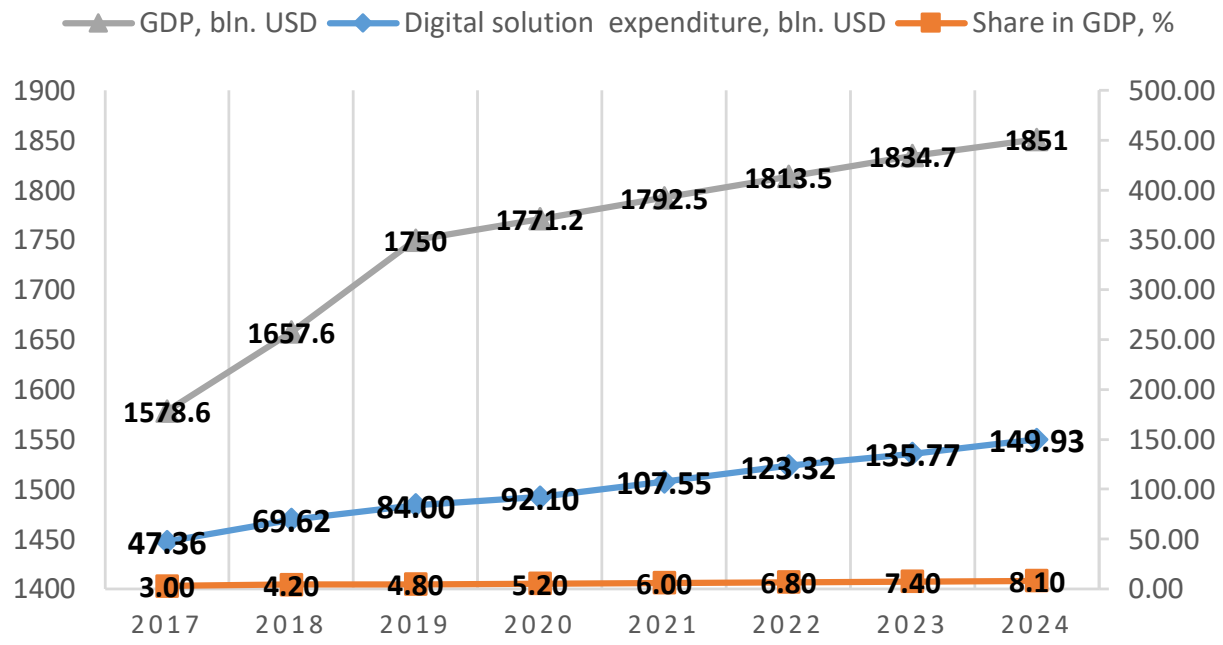

Figure2. Prognosis of Russia's digital economy share in GDP, \%

Ongoing the resource planning and customer relationship management systems' extension will provide growth of sales 5-7\% annually of B2B client-related solutions. Respectively the penetration will be $25 \%$ in the retail and wholesale chains and manufacturing sectors. Extension of the platform-driven interactions in segment B2G trading platforms for government and municipal procurement targeted at penetration $25 \%$. With respect to cloud technologies, the government is in the planning phase and has committed to migrating 90 percent of data resources to the state cloud by 2024 (The World Bank, 2018).

\section{DISCUSSION}

Will the digital transformation assist in becoming Russia, a global leader in innovation development? A number of issues to be resolved on the path of digital transformation. First, Russia needs to overcome immunity to innovation in the economy and the social spheres. It has a positive experience in implementing large-scale technological projects. A problem remains with the economy and society's immunity to innovation, which prevents applying the research results. 
The results are not optimistic. The contribution of innovation in total economic output is 8-9\%. Intangible asset investments in Russia are lower in 3-10 times compared to the leader countries. A share of Russia's high-tech in the global export is $0,4 \%$. There is a gap in the transfer of knowledge and technology between the defense and civil sectors, which hinders the development and applying of dual-use technologies.

Digital technologies penetration and competency should match to-date requirements. According to the Global information technologies report, the Russian Federation takes 41 ranks in digital economy readiness (NRI network readiness index) taking place in the middle of the second group of countries in the digital economy and society index (I-DESI). The citizens recognize the need to have a digital competency, but using of personal computers and the Internet and telecommunications network in the Russian Federation is still lower than in Europe. There is a gap in digital skills between different population groups. In 2018, the proportion of the population with digital skills was only $26 \%$, according to an international PIAAC study. The application of digital technologies in the education system is expanding, but a volume of specialized training and compliance of educational programs with the digital economy's needs is insufficient.

What are the prospective country's ranks among the world innovation leaders in 2024? The core issue is winning the talent battle. Russia's low position in the Global Talent Competitiveness Index (53-rd position in 2018) reflects a low human potential in the development of digital technologies in the economy. It determines the need to attract qualified foreign specialists and support talented schoolchildren and students in mathematics and computer science (Strack et al.,2018).

It worth noting a cyclical error on this path. Many industries have not yet adopted emerging technologies, such as IoT and cloud computing, and have a few digital security specialists. The number of industrial robots per worker in the manufacturing sectors less in 20 times than in China. As McKinsey remarks, the lack of a digital culture within the Russian industry also has the compounding effect of making companies unattractive to relevant specialists. With an inability to attract digital talent, companies simply cannot develop required digital tools, products, and services. It has a negative impact on the Russian economy's competitive position (Goran et al., 2017; The Boston Consulting Group, 2016; McKinsey \& Company, 2017).

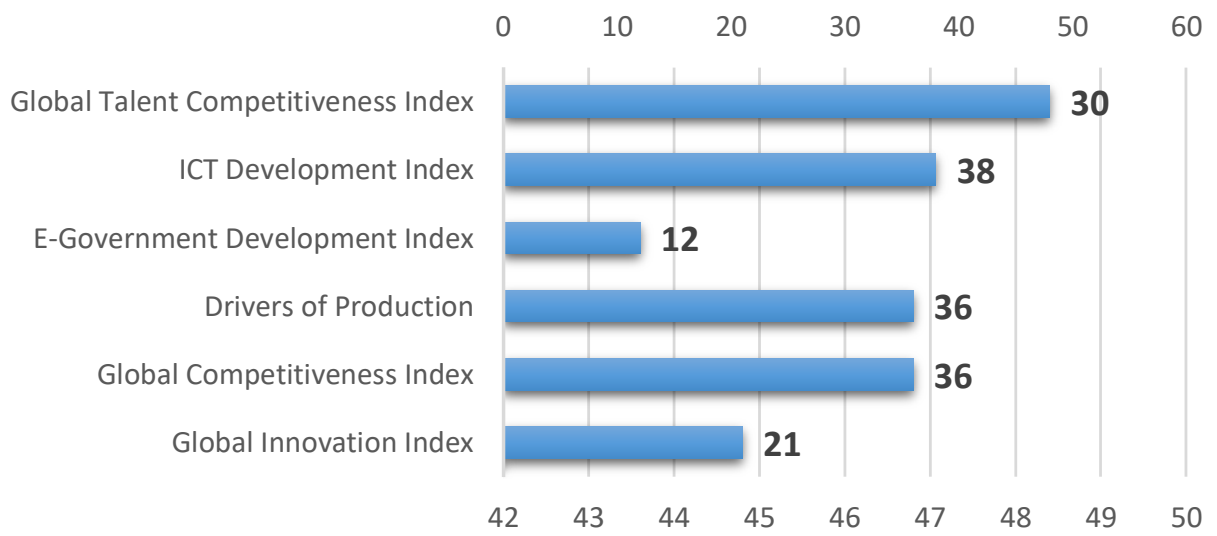

Figure 3. Prognosis for Russia's global innovation and economic ranks, 2024

The government aims at 30 positions in 2024 in the Global Talent Competitiveness Index (Figure3). It attempts to support education initiatives, build digital industry skills, counteract the brain drain, and attract leading Russian and foreign specialists. Meanwhile, in 2018, the total number of employees engaged in research and development shrank by 16,0 thousand (Shashlo, 2018). Since 2010, the number of researchers under the age of 39 has been increased by 26.7 thousand. Schoolchildren and students traditionally find 
themselves among the leaders of international competitions in the field of natural and technical disciplines, but not everyone has realized in this field.

In terms of the overall innovation process, Russia's advance is more noticeable. Considering the quality of the business environment, Russia takes ranks 28 in the 2020 World Bank Doing Business Indicator, up from 123 in 2011, now close to Japan (29), Spain (30), and China (31) (The World Bank, 2020). In high-tech export, Russia's contribution in the export of digital goods and services is 0,5 percent of GDP. Worth noting, in India 2,9 percent and China, 5,8 percent. Export of software, mainly offshore software development, was the fastest-growing export service niche with an average growth rate of $15 \%$ (The World Bank, 2018). The government supports the private sector R\&D in Russia, including both direct funding and indirect instruments such as tax incentives.

The country has a relatively high rank of 28 among 130 countries in the WEF Index of Human Capital. Russia has great experience in education in different age groups and in participation in higher education among those ages 15-24 (14th place). On the other hand, according to a WEF survey of business managers of the educational system's compliance with the tasks of ensuring the competitiveness of the economy, Russia occupies $69^{\text {th }}$ place out of 138 countries (3.7 on a seven-point scale). In the PISA in reading, mathematics, and science, Russia occupies 26th place out of 71, with an index value of 491.8, well behind the leaders, Singapore and Hong Kong SAR, China. In an assessment of the quality of science education, Russia stands below the OECD average while in math, it is slightly above it, has shown significant improvement in the last six years (The World Bank, 2017).

To reach higher ranks in innovation, Russia should overcome a research inefficiency or so-called "unchained" innovation cycle. It is worth noticing that public investment in human capital actually increases the competitiveness of other economies. As a result, Russia has lost the ability to retain the most influential scientists, engineers, and entrepreneurs who create breakthrough products. At the end of 2017, a number of organizations in research and development amounted to 3,944. At the same time, there is a significant differentiation of scientific and educational organizations in terms of performance and efficiency. Research potential is concentrated just in a few regions of the country that stipulate a regional development disproportion.

\section{CONCLUSION}

We should remark, if Russia fails to conduct the digital transformation of the economy efficiently and neglects its potential, it risks stay behind more successful countries and will not be able to provide its economic sovereignty. There is no lack of public support for innovation and technology entrepreneurship in Russia, but a problem remains with the economy and society's immunity to innovation, which prevents the practical applying of research and development results. The research indicates a significant impact of Russia's digital sector in B2B, B2G, and B2C segments, though there are signs that the existing policy may not be targeted optimally, and there is a lack of alignment and coordination.

Despite a relatively high rank of the digital economy, the sectors' contribution to the Russian economy is significantly less than the advanced countries. The core issue is to win the talent battle for challenging the highest rank in the global innovation race. To contract the gap between demand and offering digital skills, Russia needs influential scientists, engineers, and entrepreneurs who might create breakthrough products. The government aims at the highest positions in 2024 in the global completion ranking. Thus, it should support education initiatives, build digital industry skills, counteracts the brain drain, and attract leading Russian and foreign specialists to the country. 


\section{REFERENCES}

Di Maio, A., Howard, R., Archer, G. (2015). Introducing the Gartner Digital Government Maturity Model. Gartner. https://www.gartner.com/doc/3135317/introducing-gartner-digital-government-maturity

Evans, D. (2013). Economics of Vertical Restraints for Multi-Sided Platforms. Coase-Sandor Institute for Law \& Economics Working Paper No. 626.

Finck, M. (2017). Digital Co-Regulation: Designing a Supranational Legal Framework for the Platform Economy. LSE Law, Society and Economy Working Papers, 15. London School of Economics and Political Science, Department of Law, London, UK.

G.V. Petruk, Y.S. Lebedinskaya, N. A. Klescheva, A.A. Korostelev (2018) Internationalization of higher education of China as the factor of university competitiveness increase. Revista san Gregorio, No.25,SPECIAL EDITION. November, PP. 178-185.

Goran, J., Srinivasan R., LaBerge L. (2017). Culture for a digital age/ McKins\& Company https://www.mckinsey.com/business-functions/mckinsey-digital/our insights/culture-for-a-digital-age

http://revista.sangregorio.edu.ec/index.php/REVISTASANGREGORIO/article/view/766/23-GAL

Margetts, H., Naumann, A. (2017). Government as a Platform: What Can Estonia Show the World? Research paper. Oxford Internet Institute, University of Oxford. https://www.politics.ox.ac.uk/publications/government-as-a-platformwhat-can-estonia-show-the-world.html

McKinsey \& Company (2017). Digital Russia: A New Reality www.tadviser.ru/images/c/c2/Digital-Russia-report.pdf

Shashlo N.V., Petruk G.V., Korostelev A.A (2018). Determinants of integration interaction among the subjects of the entrepreneurial innovation ecosystem of macro region. Amazonia Investiga. T. 7. № 13. C. 351-363.

Strack, R., Kovács-Ondrejkovic, O., Antebi, P., Schudey, A., Ignatova, M., Oblov, A. (2018). Decoding Global Talent: Russia Faces a Talent Conundrum The Boston Consulting Group, https://www.bcg.com/publications/2018/russiafaces-talent-conundrum-global-talent.aspx

The Boston Consulting Group. (2017). Four Priorities for Breakthrough in Digital Economy https://www.bcg.com/en$\mathrm{ru} / \mathrm{d} /$ news/17oct2017-digital-economy-174478

The European Commission (2019). Digital Economy and Society Index Report file://sysprofiles.adm.vvsu.ru/emplprofiles\$/apre12014/Downloads/2019DESIICTprojectsinHorizon2020.pdf

The World Bank. (2018). Russia $\quad$ Economic $\quad$ oo39. http://pubdocs.worldbank.org/en/162681527086868170/RER-39-Eng.pdf

The World Bank. (2020). Doing Business 2020. Washington, DC: World Bank. https://www.doingbusiness.org/en/reports/global-reports/doing-business-2020

Varkulevich, T.V., Shumik, E.G., Baturina, O.A. (2018) Strategic partnership of universities as a tool of territorial development dynamics: Regional aspect. Espacios, 39 (2), 31.

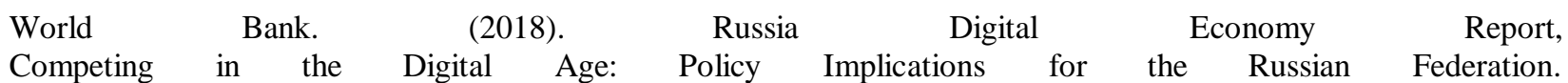

Washington, D.C.: World Bank

World Economic Forum The Global Human Capital Report (2017). https://weforum.ent.box.com/s/dari4dktg4jt2g9xo2o5pksjpatvawdb 